\title{
EFEKTIFITAS PEMBELAJARAN MATEMATIKA MENGGUNAKAN \\ PENDEKATAN KONTEKSTUAL TERHADAP PRESTASI BELAJAR \\ MATEMATIKA DITINJAU DARI KEMAMPUAN AWAL \\ SISWA KELAS V SD SE-KECAMATAN BANGUNREJO \\ KABUPATEN LAMPUNG TENGAH
}

\author{
Tri Andari \\ FPMIPA IKIP PGRI Madiun
}

\begin{abstract}
ABSTRAK
EFEKTIFITAS PEMBELAJARAN MATEMATIKA MENGGUNAKAN $\underline{\text { PENDEKATAN KONTEKSTUAL TERHADAP }}$ PRESTASI BELAJAR

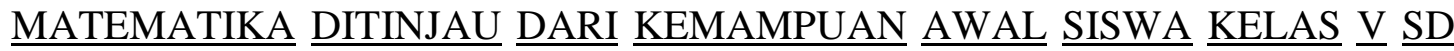

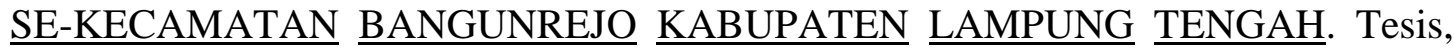
Surakarta: Pendidikan Matematika Program Pascasarjana Universitas Sebelas Maret Surakarta. 2010.

Penelitian ini bertujuan untuk mengetahui:(1) apakah prestasi belajar matematika siswa dengan menggunakan pendekatan kontekstual lebih baik dibandingkan siswa dengan menggunakan pendekatan konvensional pada materi pokok bangun datar (2) apakah siswa yang mempunyai kemampuan awal tinggi lebih baik dari prestasi belajarnya dari pada siswa yang mempunyai kemampuan awal sedang dan rendah, dan siswa yang mempunyai kemampuan awal sedang lebih baik prestasi belajarnya dibandingkan dengan siswa yang mempunyai kemampuan awal rendah pada materi pokok bangun datar. (3) apakah pada siswa yang memiliki kemampuan awal sedang, prestasi belajar siswa yang diberi pembelajaran matematika dengan pendekatan kontekstual lebih baik dibandingkan dengan siswa yang diberi pembelajaran matematika dengan pendekatan konvensional. Di sisi lain, pada siswa yang memiliki kemampuan awal tinggi atau rendah, prestasi belajar siswa yang diberi pembelajaran matematika dengan pendekatan kontekstual sama dengan siswa yang diberi pembelajaran matematika dengan pendekatan konvensional, pada materi pokok bangun datar.
\end{abstract}

Penelitian ini merupakan penelitian eksperimental semu. Populasi dalam penelitian ini adalah seluruh siswa kelas V SD di Kecamatan Bangunrejo tahun pelajaran 2009/2010. Sampel yang digunakan dalam penelitian ini adalah kelompok 
eksperimen yang terdiri dari SD N I Bangunrejo, SD N Sinarseputih, dan SD N 02 Bangunrejo. Sedangkan kelompok kontrol SD N 03 Bangunrejo, SD N I Sidoluhur, dan SD N 02 Sidoluhur yang diperoleh dengan cara stratified cluster random sampling cara undian. Teknik pengambilan data adalah dengan menggunakan tes untuk mengetahui prestasi belajar matematika siswa pada materi pokok bangun datar. Teknik analisis data yang digunakan adalah analisis variansi dua jalan dengan sel tak sama.

Berdasarkan hasil penelitian dapat disimpulkan bahwa: (1) Pembelajaran matematika dengan menggunakan pendekatan kontekstual pada pokok materi bangun datar menghasilkan prestasi belajar matematika lebih baik apabila dibandingkan menggunakan pendekatan konvensional. $\left(\mathrm{F}_{\mathrm{a}}=9,8067>\mathrm{F}_{\text {tabel }}=3,8410\right)$;

Kemampuan awal siswa memberikan pengaruh yang berbeda terhadap prestasi belajar matematika siswa pada pokok materi bangun datar. $\left(F_{b}=3,0904>F_{\text {tabel }}=3,0000\right)$. Siswa yang memiliki kemampuan awal tinggi mempunyai prestasi belajar matematika siswa yang sama dengan siswa yang mempunyai kemampuan awal sedang, siswa yang memiliki kemampuan awal tinggi mempunyai prestasi belajar matematika siswa yang lebih baik dengan siswa yang mempunyai kemampuan awal rendah, dan siswa yang memiliki kemampuan awal sedang mempunyai prestasi belajar matematika siswa yang sama dengan siswa yang mempunyai kemampuan awal rendah. (3) Tidak ada interaksi antara pendekatan pembelajaran yang digunakan dengan kemampuan awal siswa terhadap prestasi belajar matematika siswa pada materi pokok bangun datar $\left(\mathrm{F}_{\mathrm{ab}}=0,5698<\mathrm{F}_{\text {tabel }}=3,0000\right)$. Artinya siswa yang mengikuti pembelajaran matematika dengan menggunakan pendekatan kontekstual mempunyai prestasi belajar yang lebih baik daripada siswa yang mengikuti pembelajaran matematika dengan menggunakan pendekatan konvensional baik secara umum maupun kalau ditinjau dari masing-masing kategori kemampuan awal. Di sisi lain siswa dengan kemampuan awal tinggi mempunyai prestasi belajar yang lebih baik dengan siswa dengan kemampuan awal sedang dan rendah, siswa dengan kemampuan awal sedang mempunyai prestasi belajar yang lebih baik dengan siswa dengan kemampuan awal rendah baik siswa yang mengikuti pembelajaran matematika dengan menggunakan 1 kontekstual maupun siswa yang mengikuti pembelajaran matematik menggunakan pendekatan konvensional.

\section{LATAR BELAKANG MASALAH}


Kebutuhan akan pemahaman dan penerapan konsep-konsep matematika di berbagai lapangan kehidupan belum disadari dengan baik, karena kenyataan menunjukkan bahwa prestasi belajar siswa dalam mata pelajaran matematika relatif rendah sehingga sangat jarang ditemukan siswa yang memahami konsep dan penerapan matematika dengan baik.

Berdasarkan data yang diperoleh dari UPT Dinas Pendidikan Kecamatan Bangunrejo menyatakan bahwa sebanyak 41 Sekolah Dasar di Kecamatan Bangunrejo masih mendapat nilai rendah dalam Ujian Akhir Sekolah Berstandar Nasional (UASBN) atau Ujian Nasional (Unas). Rata-rata nilai yang diujikan dalam UASBN tahun pelajaran 2008/2009 diantaranya adalah nilai rata-rata mata pelajaran Bahasa Indonesia 6,33; nilai rata-rata mata pelajaran Matematika 4,62; dan nilai rata-rata mata pelajaran Ilmu Pengetahuan Alam 5,58. Dari ketiga mata pelajaran tersebut terlihat jelas bahwa nilai rata-rata yang terendah adalah pada nilai matematika.

Pada umumnya pembelajaran matematika di sekolah masih terpusat pada guru sehingga posisi guru sangat dominan. Akibatnya kegiatan belajar mengajar lebih menekankan pada pengajaran dari pada pembelajaran. Mengajar hanya merupakan transfer pengetahuan dari guru ke siswa sehinga belajar matematika hanya dengan menghafal dan mengingat rumus. Agar pembelajaran berpusat pada siswa, guru perlu memilih pendekatan pembelajaran yang memerlukan keterlibatan siswa secara aktif selama proses pembelajaran berlangsung sehingga tujuan pembelajaran dapat tercapai.

Salah satu pendekatan pembelajaran yang lebih memberdayakan siswa adalah pendekatan kontekstual. Pendekatan kontekstual merupakan konsep belajar yang membantu guru mengaitkan antara materi yang diajarkan dengan situasi dunia nyata siswa dan mendorong siswa membuat hubungan antara pengetahuan yang dimilikinya dengan penerapannya dalam kehidupan mereka sebagai anggota keluarga dan masyarakat. (www.geocities.com/pakguruonline).

Selain faktor pendekatan dalam proses pembelajaran, faktor kemampuan awal siswa berbeda-beda satu sama lain juga perlu diperhatikan. Hal tersebut memungkinkan terjadinya perbedaan penerimaan materi masing-masing siswa. Sehingga berakibat pula pada perbedaan hasil belajar mereka. Kemampuan awal siswa akan berpengaruh pada pemahaman siswa pada materi selanjutnya, karena matematika adalah mata pelajaran yang terorganisasikan, dimulai dari unsur-unsur yang tidak didefinisikan ke unsur yang didefinisikan, selanjutnya ke postulat atau aksioma sampai ke dalil atau teorema. Maka pembelajaran matematika harus 
dilakukan secara hierarkis. Dalam pembelajaran matematika ada persyaratan tertentu yang harus dipenuhi sebelum suatu konsep tertentu dipelajari.

\section{Identifikasi Masalah}

Berdasarkan latar belakang masalah di atas, maka identifikasi masalah dalam penelitian ini adalah sebagai berikut:

1. Pendekatan pembelajaran yang sesuai materi dan tujuan pembelajaran akan membuat siswa benar-benar memahami materi dan menguasai konsep. Akan tetapi masih banyak guru yang menggunakan pendekatan konvensional di setiap proses pembelajaran, padahal tidak semua pendekatan dan pendekatan dapat digunakan dalam tiap materi pokok. Terkait dengan hal ini muncul pertanyaan apakah jika pendekatannya diubah maka prestasi siswa akan meningkat.

2. Selain faktor model dan pendekatan pembelajaran dalam proses pembelajaran, faktor kemampuan awal siswa berbeda-beda satu sama lain juga perlu diperhatikan. Kemampuan awal adalah salah satu faktor intern yang mempengaruhi prestasi belajar siswa, tetapi banyak dijumpai siswa dengan kemampuan awal yang tinggi tidak dapat mencapai prestasi belajar yang baik, begitu pula sebaliknya sehingga perlu dikaji lebih lanjut bagaimana pengaruh kemampuan awal siswa terhadap prestasi belajarnya.

3. Rendahnya prestasi belajar matematika siswa mungkin berkaitan dengan aktivitas belajar siswa, mengingat dalam belajar sangat diperlukan adanya aktivitas, tanpa aktivitas belajar itu tidak mungkin akan berlangsung dengan baik. Mengenai hal itu, maka perlu diteliti apakah jika semakin tinggi aktivitas siswa dalam belajar matematika semakin tinggi pula prestasi belajar matematikanya.

4. Rendahnya prestasi belajar siswa mungkin disebabkan siswa kesulitan dalam menerapkan konsep matematika yang ia terima di sekolah ke dalam kehidupannya sehari-hari. Mengenai hal ini dapat dilakukan penelitian apakah jika dilakukan pembelajaran yang dapat mengaitkan dengan konsep matematika dengan kehidupan sehari-hari dapat meningkatkan prestasi belajar siswa atau tidak.

\section{Pemilihan Masalah}

Karena keterbatasan peneliti, maka dalam penelitian ini hanya mencoba menyelesaikan masalah nomor 1, 2 dan 4 dari ke-empat masalah pada identifikasi masalah di atas.

\section{Pembatasan Masalah}


Berdasarkan identifikasi masalah di atas, agar permasalahan yang akan dikaji lebih terarah maka masalah-masalah tersebut dibatasi sebagai berikut :

1. Pendekatan pembelajaran dalam penelitian ini dibatasi pada pendekatan pembelajaran menggunakan pendekatan kontekstual pada kelompok eksperimen dan pendekatan konvensional pada kelompok kontrol.

2. Prestasi belajar matematika siswa pada penelitian ini dibatasi pada prestasi belajar pada materi pokok bangun datar yang dilakukan pada akhir penelitian.

3. Kemampuan awal siswa adalah kemampuan matematika siswa saat penelitian ini hendak dilakukan. Kemampuan awal siswa ini diperoleh dari nilai matematika siswa pada ulangan semester genap kelas IV SD Negeri di Kecamatan Bangunrejo tahun pelajaran 2008/2009, yang dibedakan dalam tiga kategori yaitu tinggi, sedang, dan rendah.

4. Penelitian ini dilakukan pada siswa kelas V SD di Kecamatan Bangunrejo Kabupaten Lampung Tengah Provinsi Lampung.

\section{Perumusan Masalah}

Berdasarkan pembatasan masalah dapat dirumuskan permasalahan sebagai berikut

1. Apakah prestasi belajar matematika siswa dengan menggunakan pendekatan kontekstual lebih baik dibandingkan siswa dengan menggunakan pendekatan konvensional pada materi pokok bangun datar?

2. Apakah siswa yang mempunyai kemampuan awal tinggi lebih baik dari prestasi belajarnya dari pada siswa yang mempunyai kemampuan awal sedang dan rendah, dan siswa yang mempunyai kemampuan awal sedang lebih baik prestasi belajarnya dibandingkan dengan siswa yang mempunyai kemampuan awal rendah pada materi pokok bangun datar?

3. Apakah pada siswa yang memiliki kemampuan awal sedang, prestasi belajar siswa yang diberi pembelajaran matematika dengan pendekatan kontekstual lebih baik dibandingkan dengan siswa yang diberi pembelajaran matematika dengan pendekatan konvensional. Di sisi lain, pada siswa yang memiliki kemampuan awal tinggi atau rendah, prestasi belajar siswa yang diberi pembelajaran matematika dengan pendekatan kontekstual sama dengan siswa yang diberi pembelajaran matematika dengan pendekatan konvensional, pada materi pokok bangun datar?

\section{Tujuan Penelitian}


Bertolak dari perumusan masalah, penelitian ini bertujuan :

1. Untuk mengetahui apakah prestasi belajar matematika siswa dengan menggunakan pendekatan kontekstual lebih baik dibandingkan siswa dengan menggunakan pendekatan konvensional pada materi pokok bangun datar.

2. Untuk mengetahui apakah siswa yang mempunyai kemampuan awal tinggi lebih baik dari prestasi belajarnya dari pada siswa yang mempunyai kemampuan awal sedang dan rendah, dan siswa yang mempunyai kemampuan awal sedang lebih baik prestasi belajarnya dibandingkan dengan siswa yang mempunyai kemampuan awal rendah pada materi pokok bangun datar.

3. Untuk mengetahui apakah pada siswa yang memiliki kemampuan awal sedang, prestasi belajar siswa yang diberi pembelajaran matematika dengan pendekatan kontekstual lebih baik dibandingkan dengan siswa yang diberi pembelajaran matematika dengan pendekatan konvensional. Di sisi lain, pada siswa yang memiliki kemampuan awal tinggi atau rendah, prestasi belajar siswa yang diberi pembelajaran matematika dengan pendekatan kontekstual sama dengan siswa yang diberi pembelajaran matematika dengan pendekatan konvensional, pada materi pokok bangun datar.

\section{Manfaat Penelitian}

Hasil penelitian ini diharapkan dari penelitian ini adalah :

1. Bagi Guru dan Calon Guru

a. Sebagai alternatif pemilihan pendekatan pembelajaran dalam matematika.

b. Menambah wawasan dalam rangka perubahan paradigma pembelajaran dari paradigma mengajar ke paradigma belajar.

c. Menambah pengetahuan tentang pembelajaran kontekstual.

2. Bagi Siswa
a. Lebih memotivasi dalam belajar matematika
b. Melatih kemandirian dalam belajar
c. Mengembangkan sikap siswa dalam memecahkan masalah matematika

\section{TINJAUAN PUSTAKA}

"Prestasi belajar adalah penguasaan ilmu pengetahuan atau ketrampilan yang dikembangkan oleh mata pelajaran, lazimya ditunjukkan dengan nilai tes atau angka nilai yang diberikan guru." (KBBI 2005 : 787) 
Matematika merupakan suatu ilmu yang mempelajari jumlah-jumlah yang diketahui melalui proses perhitungan dan pengukuran yang dinyatakan dengan angkaangka dan simbol-simbol.

Berdasarkan pengertian prestasi belajar dan matematika yang telah diuraikan di atas, dapat ditarik kesimpulan bahwa prestasi belajar matematika adalah hasil yang telah dicapai siswa dalam mengikuti pelajaran matematika yang mengakibatkan perubahan pada diri seorang siswa berupa penguasaan dan kecakapan baru yang ditunjukan dengan hasil yang berupa nilai.

\section{Pembelajaran dengan Pendekatan Kontekstual}

Depdiknas (2003:1) menyatakan bahwa "Pendekatan kontekstual merupakan konsep belajar yang membantu guru mengaitkan antara materi yang diajarkannya dengan situasi dunia nyata siswa dan mendorong siswa membuat hubungan antara pengetahuan yang dimilikinya dengan penerapannya dalam kehidupan mereka sebagai anggota keluarga dan masyarakat.”

\section{Kemampuan Awal}

Dalam proses belajar mengajar, untuk memahami hal-hal baru orang memerlukan modal berupa kemampuan yang telah melekat padanya dan yang terkait dengan hal baru yang akan dipelajari tersebut. Kemampuan yang telah melekat pada seseorang dan yang terkait dengan hal baru yang akan dipelajari selanjutnya disebut kemampuan awal. (Pentatito, 2008: 28)

\section{Kerangka Pemikiran}

Prestasi belajar matematika umumnya lebih rendah bila dibandingkan degan mata pelajaran yang lain. Hal ini disebabkan oleh banyak faktor baik internal maupun eksternal. Belajar matematika merupakan belajar konsep. Untuk mencapai tujuan pembelajaran diperlukan pendekatan pembelajaran yang tepat. Guru harus menpunyai strategi agar siswa dapat belajar secara efektif dan efisien. Oleh karena itu pemilihan pendekatan mengajar yang tepat sangat penting, karena tidak semua pendekatan dapat digunakan pada tiap materi pokok. Salah satu pendekatan yang dapat digunakan adalah pendekatan pembelajaran menggunakan pendekatan kontekstual. Proses menyelesaikan masalah pada tiap siswa tidaklah sama. Hal ini dikarenakan kemampuan awal mereka yang berbeda-beda. Siswa yang memiliki kemampuan awal yang lebih tinggi dimungkinkan akan lebih cepat menyelesaikan masalah dibandingkan teman-temannya yang berkemampuan awal lebih rendah. Penggunaan 
pendekatan pembelajaran menggunakan pendekatan kontekstual akan berlangsung lancar dan berhasil baik jika didukung dengan kemampuan awal siswa yang baik.

\section{Perumusan Hipotesis}

Berdasarkan kerangka pemikiran di atas, dapat dirumuskan hipotesis sebagai berikut :

1. Prestasi belajar matematika siswa dengan menggunakan pendekatan kontekstual lebih baik dibandingkan siswa dengan menggunakan pendekatan konvensional pada materi pokok bangun datar.

2. Siswa yang mempunyai kemampuan awal tinggi lebih baik dari prestasi belajarnya dari pada siswa yang mempunyai kemampuan awal sedang dan rendah, dan siswa yang mempunyai kemampuan awal sedang lebih baik prestasi belajarnya dibandingkan dengan siswa yang mempunyai kemampuan awal rendah pada materi pokok bangun datar.

3. Pada siswa yang memiliki kemampuan awal sedang, prestasi belajar siswa yang diberi pembelajaran matematika dengan pendekatan kontekstual lebih baik dibandingkan dengan siswa yang diberi pembelajaran matematika dengan pendekatan konvensional. Di sisi lain, pada siswa yang memiliki kemampuan awal tinggi atau rendah, prestasi belajar siswa yang diberi pembelajaran matematika dengan pendekatan kontekstual sama dengan siswa yang diberi pembelajaran matematika dengan pendekatan konvensional, pada materi pokok bangun datar".

\section{METODOLOGI}

\section{Tempat dan Waktu Penelitian}

Penelitian ini dilakukan di Sekolah Dasar di Kecamatan Bangunrejo Kabupaten Lampung Tengah yang dilaksanakan pada semester satu tahun pelajaran 2009/2010.

\section{Metode Penelitian}

Pendekatan penelitian yang digunakan adalah pendekatan eksperimental semu (quasy eksperimen

\section{Populasi, Sampel, dan Teknik Pengambilan Sampel}

Dalam penelitian ini yang akan menjadi populasi adalah siswa kelas $\mathrm{V}$ Sekolah Dasar di Kecamatan Bangunrejo Kabupaten Lampung Tengah. 
Sampel yang diambil dalam penelitian ini sebanyak enam SD yang terdiri dari tiga SD untuk kelompok eksperimen dan tiga SD untuk kelompok kontrol.

Pengambilan sampel dilakukan dengan cara stratified cluster random sampling. Populasi dari stratified cluster random sampling ini adalah seluruh siswa SD di Kecamatan Bangunrejo tahun pelajaran 2009/2010.

\section{Identifikasi Variabel}

Dalam penelitian ini terdapat dua variabel bebas dan satu variabel terikat. Variabel bebas meliputi pendekatan pembelajaran dan kemampuan awal siswa sedangkan variabel terikatnya adalah prestasi belajar matematika siswa.

\section{Teknik Pengumpulan Data}

Pendekatan yang digunakan utuk mengumpulkan data dalam penelitian ini adalah sebagai berikut :

\section{a. Pendekatan Dokumentasi}

Pendekatan dokumentasi yang digunakan pada penelitian ini adalah untuk memperoleh data tentang kemampuan awal siswa yang diambil dari nilai ulangan harian matematika pada bab pengukuran waktu, sudut, jarak dan kecepatan yang digunakan dalam menguji keseimbangan antara kelas eksperimen dan kelas kontrol.

\section{b. Pendekatan Tes}

Pendekatan tes digunakan untuk mengumpulkan data mengenai prestasi belajar matematika pada materi pokok bangun datar setelah dikenai suatu perlakuan. Tes ini berupa soal-soal mengenai materi materi pokok bangun datar.

\section{Instrumen Penelitian}

a. Tahap Penyusunan

- Menyusun kisi-kisi instrumen yaitu kisi-kisi tes pada materi pokok bangun datar.

- Menyusun soal berdasarkan kisi-kisi tes yang telah dibuat.

- Menentukan penskoran pada setiap item soal.

\section{b. Tahap Uji Coba}

Tahap uji coba ini meliputi: validitas isi, uji reliabilitas, daya pembeda dan tingkat kesukaran. 


\section{Teknik Analisis Data}

1. Uji Keseimbangan

Statistik uji yang digunakan adalah uji-t.

2. Uji Prasyarat Analisis

a. Uji Normalitas

Untuk uji normalitas digunakan pendekatan Lilliefors.

b. Uji Homogenitas Variansi

Uji homogenitas dalam penelitian ini menggunakan himpunan pendekatan Bartlett.

\section{Uji Hipotesis}

Dalam penelitian ini digunakan uji hipotesis dengan analisis variansi dua jalan dengan sel tak sama.

\section{Uji Komparasi Ganda}

Uji lanjut pasca anava adalah tindak lanjut dari analisis variansi apabila hasil analisis variansi tersebut menunjukkan bahwa hipotesis nol ditolak.

\section{HASIL PENELITIAN DAN PEMBAHASAN}

\section{Hasil Uji Coba Instrumen Tes Prestasi Belajar Matematika}

Berdasarkan uji validitas isi yang dilakukan validator, mempertimbangkan saran dari validator untuk melakukan revisi pada beberapa butir soal, maka semua soal dapat digunakan untuk instrumen penelitian.

Berdasarkan uji daya pembeda dari 30 butir soal yang diujicobakan ternyata terdapat 2 butir soal yang tidak memenuhi kriteria atau nilai $\mathrm{D}<0,2$. Kedua butir soal tersebut adalah soal nomor 25 dan soal nomor 29. Sedangkan 28 butir soal yang lain mempunyai nilai $\mathrm{D} \geq 0,2$ sehingga dapat digunakan sebagai instrumen untuk mengetahui prestasi belajar matematika siswa pada materi pokok bangun datar.

Berikut ini data hasil perhitungan tingkat kesukaran terhadap 30 butir soal coba tes prestasi yang dapat dilihat Tabel 4.1 di bawah ini :

Tabel 4.1 Hasil Analisis Tingkat Kesukaran

\begin{tabular}{|l|l|l|}
\hline Kategori & \multicolumn{1}{|c|}{ Nomor item } & Jumlah \\
\hline Sukar & $18 ; 20 ; 22 ; 29$ & 4 \\
\hline Sedang & $1 ; 2 ; 3 ; 4 ; 5 ; 6 ; 7 ; 8 ; 9 ; 10 ; 11 ; 12 ; 13 ; 14 ; 15 ;$ & 21 \\
& $16 ; 17 ; 19 ; 21 ; 23 ; 24 ; 25 ; 26 ; 27 ; 28 ; 30$ & \\
\hline Mudah & - & 0 \\
\hline & Jumlah & 25 \\
\hline
\end{tabular}


Dari hasil perhitungan diperoleh $\mathrm{r}_{11}=0,8259$, nilai indeks reliabilitas ini lebih dari 0,7 sehingga instrumen tes ini dikatakan reliabel.

Analisis butir soal untuk instrumen tes prestasi belajar pada penelitian ini terdiri dari validitas isi, daya pembeda, reliabilitas, dan tingkat kesukaran. Hasil perhitungan dari 30 soal yang dianalisis terdapat 5 soal yang tidak dipakai karena tidak memenuhi kriteria yaitu soal nomor $18 ; 20 ; 22 ; ; 25$; dan 29.

\section{Skor Kemampuan Awal Siswa}

Berdasarkan data yang telah terkumpul terdapat 74 siswa yang termasuk berkemampuan awal kategori tinggi, 63 siswa yang termasuk berkemampuan awal kategori sedang, dan 87 siswa yang termasuk berkemampuan awal kategori rendah dengan perincian untuk kelompok eksperimen terdapat 40 siswa yang termasuk kategori tinggi, 30 siswa yang termasuk kategori sedang, dan 40 siswa yang termasuk kategori rendah. Sedangkan untuk kelompok kontrol terdapat 34 siswa yang termasuk kategori tinggi, 33 siswa yang termasuk kategori sedang, dan 47 siswa yang termasuk kategori rendah.

\section{Data Prestasi Belajar Matematika Siswa}

Untuk memperoleh gambaran secara umum tentang ukuran tendensial sentral dan ukuram dispersi data prestasi belajar matematika siswa disajikan sebagai berikut:

\begin{tabular}{|l|c|c|c|c|c|c|c|}
\hline \multirow{2}{*}{ Kelas } & \multicolumn{2}{|c|}{ Ukuran Tendensial sentral } & \multicolumn{4}{|c|}{ Ukuran Disperdi } \\
\cline { 2 - 8 } & $\bar{X}$ & Mo & Me & $\begin{array}{c}\text { Skor } \\
\text { Min }\end{array}$ & $\begin{array}{c}\text { Skor } \\
\text { Max }\end{array}$ & $\mathrm{J}$ & $\mathrm{s}$ \\
\hline Eksperimen & 67,4545 & 68 & 55,5 & 36 & 100 & 64 & 14,5536 \\
\hline Kontrol & 61,2281 & 60 & 57,5 & 36 & 96 & 60 & 13,1661 \\
\hline
\end{tabular}

\section{Uji Keseimbangan}

Uji keseimbangan nilai ulangan harian bab pengukuran waktu, sudut, jarak dan kecepatan antara kelompok eksperimen dan kelompok kontrol dihitung menggunakan uji-t. Keseimbangan dari nilai ulangan bab sebelumnya diperoleh $\mathrm{t}_{\text {hitung }}=0,9113$ dengan $\mathrm{DK}=\{\mathrm{t} \mid \mathrm{t}<-1.960$ atau $\mathrm{t}>1.960\}$, sehingga dapat diambil kesimpulan bahwa kelompok eksperimen dan kelompok kontrol dalam keadaan setimbang atau mempunyai kemampuan awal yang sama. 


\section{Pengujian Prasyarat Analisis}

1. Uji Normalitas

Hasil uji normalitas dari tes prestasi belajar matematika dengan menggunakan uji Liliefors diperoleh harga statistik uji untuk tingkat signifikan $5 \%$

Tabel 4.2. hasil uji normalitas

\begin{tabular}{|c|l|c|c|c|c|}
\hline No & $\begin{array}{l}\text { Uji } \\
\text { normalitas }\end{array}$ & $\mathbf{L}_{\mathbf{o b s}}$ & $\begin{array}{c}\mathbf{L}_{\mathbf{0 , 0 5}} ; \\
\mathbf{n}\end{array}$ & $\begin{array}{l}\text { Keputusan } \\
\mathbf{U j i}\end{array}$ & Kesimpulan \\
\hline 1 & $\begin{array}{l}\text { Kelompok } \\
\text { Eksperimen }\end{array}$ & 0,0844 & 0,0845 & $\begin{array}{l}\mathrm{H}_{0} \\
\text { diterima }\end{array}$ & Normal \\
\hline 2 & $\begin{array}{l}\text { Kelompok } \\
\text { Kontrol }\end{array}$ & 0,0829 & 0,0830 & $\begin{array}{l}\mathrm{H}_{0} \\
\text { diterima }\end{array}$ & Normal \\
\hline 3 & $\begin{array}{l}\text { Kelompok } \\
\text { Eksperimen dan } \\
\text { kontrol dengan } \\
\text { kemampuan awal } \\
\text { tinggi }\end{array}$ & 0,0960 & 0,1030 & $\begin{array}{l}\mathrm{H}_{0} \\
\text { diterima }\end{array}$ & Normal \\
\hline 4 & $\begin{array}{l}\text { Kelompok } \\
\text { Eksperimen dan } \\
\text { kontrol dengan } \\
\text { kemampuan awal } \\
\text { sedang }\end{array}$ & 0,0781 & 0,1116 & $\begin{array}{l}\mathrm{H}_{0} \\
\text { diterima }\end{array}$ & Normal \\
\hline 5 & $\begin{array}{l}\text { Kelompok } \\
\text { Eksperimen dan } \\
\text { kontrol dengan } \\
\text { kemampuan awal } \\
\text { rendah }\end{array}$ & 0,0737 & 0,0950 & $\begin{array}{l}\mathrm{H}_{0} \\
\text { diterima }\end{array}$ & \\
\hline
\end{tabular}

Dari Tabel 4.2 terlihat bahwa $\mathrm{H}_{0}$ diterima. Ini berarti masing-masing sampel berasal dari populasi yang berdistribusi normal.

\section{Uji Homogenitas}

Hasil uji homogenitas dengan menggunakan pendekatan Bartlett disajikan dalam Tabel 4.3 berikut ini:

Tabel 4.3. hasil uji homogenitas

\begin{tabular}{|r|l|r|r|c|c|c|}
\hline $\begin{array}{l}\mathbf{N} \\
\mathbf{0}\end{array}$ & Sampel & $\mathbf{k}$ & $x^{2}$ obs & $x^{2} 0,05 ; k-1$ & $\begin{array}{c}\text { Keputusan } \\
\text { uji }\end{array}$ & Kesimpulan \\
\hline 1 & $\begin{array}{l}\text { Pendekatan } \\
\text { Pembelajaran }\end{array}$ & 2 & 0,2259 & 0,3841 & $\mathrm{H}_{0}$ diterima & Homogen \\
\hline 2 & $\begin{array}{l}\text { Kemampuan } \\
\text { Awal Siswa }\end{array}$ & 3 & 1,9455 & 5,9910 & $\mathrm{H}_{0}$ diterima & Homogen \\
\hline
\end{tabular}

Dari Tabel 4.3 terlihat bahwa harga statistik uji untuk masing-masing sampel kurang dari harga $x^{2}$ obs, sehingga $\mathrm{H}_{0}$ diterima.

\section{Pengujian Hipotesis}

1. Uji Analisis Variansi Dua Jalan Sel Tak Sama 
Hasil Perhitungan analisis variansi dua jalan sel tak sama disajikan dalam Tabel 4.4 berikut ini:

Tabel 4.4. Rangkuman hasil Analisis Variansi Dua Jalan Sel Tak Sama

\begin{tabular}{|l|r|r|r|r|r|r|}
\hline Sumber & JK & dK & RK & $\mathbf{F}_{\text {obs }}$ & $F_{\alpha}$ & Keputusan \\
\hline $\begin{array}{l}\text { Pend. } \\
\text { Pembelajaran } \\
\text { (A) }\end{array}$ & 2176,4300 & 1 & 2176,4300 & 9,8067 & 3,8410 & $\mathrm{H}_{0}$ ditolak \\
\hline $\begin{array}{l}\text { Kemampuan } \\
\text { Awal Siswa } \\
\text { (B) }\end{array}$ & 1371,8490 & 2 & 685,8490 & 3,0304 & 3,0000 & $\mathrm{H}_{0}$ ditolak \\
\hline $\begin{array}{l}\text { Interaksi } \\
\text { (AB) }\end{array}$ & 252,8963 & 2 & 126,4482 & 0,5698 & 3,0000 & $\mathrm{H}_{0}$ diterima \\
\hline Galat (G) & 48381,1933 & 218 & 221,9321 & - & - & - \\
\hline Total & 52182,2174 & 223 & - & - & - & - \\
\hline
\end{tabular}

2. Uji Komparasi Ganda

Uji komparasi ganda merupakan uji lanjut dari analisis variansi, uji tersebut dilakukan apabila hipotesis nol pada perhitungan analisis variansi ditolak, artinya terdapat sedikitnya sepasang rataan dari baris atau kolom yang berbeda secara signifikan.

a. Uji Komparasi Ganda Antar Baris

Tabel 4.5 Rataan Prestasi Belajar Siswa

\begin{tabular}{|l|c|c|c|c|}
\hline & $\begin{array}{l}\text { Kemampuan } \\
\text { Awal tinggi } \\
\left(\mathrm{b}_{1}\right)\end{array}$ & $\begin{array}{l}\text { Kemampuan } \\
\text { Awal } \\
\text { Sedang } \\
\left(\mathrm{b}_{2}\right)\end{array}$ & $\begin{array}{l}\text { Kemampuan } \\
\text { Awal } \\
\text { Rendah } \\
\left(\mathrm{b}_{3}\right)\end{array}$ & $\begin{array}{l}\text { Rataan } \\
\text { Marginal }\end{array}$ \\
\hline $\begin{array}{l}\text { Pendekatan } \\
\text { Kontekstual } \\
\left(\mathrm{a}_{1}\right)\end{array}$ & 70,2000 & 67,5667 & 65,9000 & 67,4818 \\
\hline $\begin{array}{l}\text { Pendekatan } \\
\text { Konvensional } \\
\left(\mathrm{a}_{2}\right)\end{array}$ & 64,3529 & 63,6364 & 56,7660 & 61,0175 \\
\hline $\begin{array}{l}\text { Rataan } \\
\text { Marginal }\end{array}$ & 67,5135 & 65,5238 & 60,9655 & \\
\hline
\end{tabular}

b. Uji Komparasi Ganda Antar Kolom

Tabel 4.6 Hasil uji komparasi ganda antar kolom

\begin{tabular}{|c|c|c|c|}
\hline Komparasi & $\mathbf{F}_{\text {. } . \mathbf{j} \mathbf{j}}$ & $\mathbf{2 ~ F}_{\text {Tabel }}$ & Keputusan Uji \\
\hline$\mu_{.1} v s \mu_{.2}$ & 0,6070 & 6,000 & $\mathrm{H}_{0}$ diterima \\
$\mu_{.1} v s \mu_{.3}$ & 7,7254 & 6,000 & $\mathrm{H}_{0}$ ditolak \\
$\mu_{.2} v s \mu_{.3}$ & 3,4210 & 6,000 & $\mathrm{H}_{0}$ diterima \\
\hline
\end{tabular}




\section{c.Uji Komparasi Ganda Antar Sel}

Dari hasil perhitungan analisis variansi dua jalan sel tak sama yang terangkum dalam Tabel 4.6 diperoleh keputusan bahwa $\mathrm{H}_{0 \mathrm{AB}}$ diterima. Hal ini berarti bahwa tidak terdapat interaksi anatara pendekatan pembelajaran dan kemampuan awal siswa terhadap prestasi belajar matematika pada materi pokok bangun datar sehingga tidak perlu dilakukan dilakukan uji komparasi ganda antar sel pada baris yang sama atau kolom yang sama.

\section{Pembahasan Hasil Analisa Data}

\section{Hipotesis Pertama}

Hipotesis pertama adalah "Prestasi belajar matematika siswa dengan menggunakan pendekatan kontekstual lebih baik dibandingkan siswa dengan menggunakan pendekatan konvensional pada materi pokok bangun datar".

Dari hasil anava dua jalan dengan sel tak sama diperoleh $\mathrm{Fa}=9,8067>3,84$ $=\mathrm{F}_{\text {Tabel, }}$, sehingga $\mathrm{Fa}$ anggota daerah kritik. Karena $\mathrm{Fa} \in \mathrm{DK}$ maka $\mathrm{H}_{\mathrm{OA}}$ ditolak. Hal ini berarti terdapat perbedaan prestasi belajar matematika antara siswa yang diberi pembelajaran matematika dengan pendekatan kontekstual dengan siswa yang diberi pembelajaran matematika dengan pendekatan konvensional pada materi pokok bangun datar.

\section{Hipotesis Kedua}

Hipotesis kedua adalah "siswa yang mempunyai kemampuan awal tinggi lebih baik dari prestasi belajar matematikanya daripada siswa yang mempunyai kemampuan awal sedang dan rendah, dan siswa yang mempunyai kemampuan awal sedang lebih baik prestasi belajar matematikanya dibandingkan dengan siswa yang mempunyai kemampuan awal rendah pada materi pokok bangun datar".

Dari hasil anava dua.jalan dengan sel tak sama diperoleh $F_{b}=3,0904>$ $3,0000=F_{\text {Tabel }}$ sehingga $F_{b}$ anggota daerah kritik. Karena $F_{b} \in D K$ maka $H_{o B}$ ditolak. Hal ini berarti tidak semua kategori kemampuan awal siswa memberikan efek yang sama terhadap prestasi belajar matematika matematika pada materi pokok bangun datar. Karena $\mathrm{H}_{\mathrm{oB}}$ ditolak maka diperlukan uji lanjut anava yaitu uji komparasi ganda.

Berdasarkan uji komparasi ganda antara kolom 1 dan 2 seperti yang tercantum dalam Tabel 4.6 diperoleh $\mathrm{F}_{.1-.2}=0,6070$ dan $2 \mathrm{~F}_{\text {Tabel }}=6,000$. Jadi $\mathrm{F}_{.1-2}$ $<2 \mathrm{~F}_{\text {Tabel }}$ sehingga $\mathrm{H}_{\mathrm{o}}$ diterima. 
Berdasarkan uji komparasi ganda antara kolom 1 dan 3 seperti yang tercantum dalam Tabel 4.6 diperoleh $F_{.1-.3}=7,7254$ dan $2 F_{\text {Tabel }}=6,000$. Jadi $F_{.1-3}$ $>2 \mathrm{~F}_{\text {Tabel }}$ sehingga $\mathrm{H}_{\mathrm{o}}$ ditolak. Selanjutnya berdasarkan uji komparasi ganda antara kolom 2 dan 3 seperti yang tercantum dalam Tabel 13 diperoleh $F_{.2-3}=3,4210$ dan $2 \mathrm{~F}_{\text {Tabel }}=6,000$. Jadi $\mathrm{F}_{.2-3}<2 \mathrm{~F}_{\text {Tabel }}$ sehingga $\mathrm{H}_{\mathrm{o}}$ diterima.

\section{Hipotesis Ketiga}

Hipotesisi ketiga adalah “ pada siswa yang memiliki kemampuan awal sedang, prestasi belajar siswa yang diberi pembelajaran matematika dengan pendekatan kontekstual lebih baik dibandingkan dengan siswa yang diberi pembelajaran matematika dengan pendekatan konvensional. Di sisi lain, pada siswa yang memiliki kemampuan awal tinggi atau rendah, prestasi belajar siswa yang diberi pembelajaran matematika dengan pendekatan kontekstual sama dengan siswa yang diberi pembelajaran matematika dengan pendekatan konvensional, pada materi pokok bangun datar".

Dari hasil anava dua jalan deagan sel tak sama diperoleh $\mathrm{F}_{\mathrm{ab}}=0,0156<3,00$ $=\mathrm{F}_{\text {Tabel }}$, sehingga $\mathrm{F}_{\mathrm{ab}}$ bukan anggota daerah kritik. Karena $\mathrm{F}_{\mathrm{ab}} \notin \mathrm{DK}$ maka $\mathrm{H}_{\mathrm{OAB}}$ diterima. Karena $\mathrm{H}_{\mathrm{OAB}}$ diterima maka tidak diperlukan uji lanjut anava. Dengan diterimanya $\mathrm{H}_{\mathrm{OAB}}$ berarti Tidak terdapat interaksi antara penggunaan pendekatan pembelajaran dan kemampuan awal siswa terhadap prestasi belajar matematika matematika siswa pada materi pokok bangun datar.

\section{KESIMPULAN, IMPLIKASI DAN SARAN}

\section{Kesimpulan}

Berdasarkan kajian teori dan didukung adanya analisis hasil penelitian serta mengacu pada perumusan masalah yang telah diuraikan pada bab sebelumnya, dapat disimpulkan beberapa hal sebagai berikut :

1. Pembelajaran matematika menggunakan pendekatan kontekstual pada materi pokok bangun datar menghasilkan prestasi belajar matematika yang lebih baik dibanding dengan menggunakan pendekatan konvensional.

2. Kemampuan awal siswa berpengaruh terhadap prestasi belajar matematika pada materi pokok bangun datar kelas V SD semester I tahun pelajaran 2009/2010. Prestasi belajar matematika siswa yang mempunyai kemampuan awal tinggi sama baiknya dengan siswa yang mempunyai kemampuan awal sedang, prestasi 
belajar matematika siswa yang mempunyai kemampuan awal tinggi lebih baik dibandingkan dengan siswa yang mempunyai kemampuan awal rendah, dan prestasi belajar matematika siswa yang mempunyai kemampuan awal sedang sama dengan siswa yang mempunyai kemampuan awal rendah.

3. Tidak terdapat interaksi antara penggunaan pendekatan pembelajaran dan kemampuan awal siswa terhadap prestasi belajar matematika matematika siswa pada materi pokok bangun datar. Artinya siswa yang mengikuti pembelajaran matematika dengan menggunakan pendekatan kontekstual mempunyai prestasi belajar yang lebih baik daripada siswa yang mengikuti pembelajaran matematika dengan menggunakan pendekatan konvensional baik secara umum maupun kalau ditinjau dari masing-masing kategori kemampuan awal.

\section{Implikasi}

Berdasarkan pada kajian teori serta mengacu pada hasil penelitian ini, maka penulis akan menyampaikan implikasi yang berguna baik secara teoritis maupun secara praktis dalam upaya meningkatkan prestasi belajar matematika.

\section{Implikasi Teoritis}

Hasil penelitian ini menyatakan bahwa terdapat perbedaan prestasi belajar siswa yang mengikuti pembelajaran matematika dengan menggunakan pendekatan kontekstual dengan siswa yang mengikuti pembelajaran matematika dengan menggunakan pendekatan konvensional. Hal ini menunjukkan secara teoritis hasil penelitian ini dapat digunakan sebagai salah satu acuan untuk mengembangkan pendekatan pembelajaran pada materi pokok bangun datar pada khususnya dan materi pokok yang lain pada umumnya.

Dari hasil penelitian diperoleh bahwa terdapat perbedaan prestasi belajar siswa pada materi pokok bangun datar antara siswa yang mengikuti pembelajaran matematika dengan pendekatan kontekstual dengan siswa yang mengikuti pembelajaran matematika dengan pendekatan konvensional.

Ditinjau dari nilai rata-rata prestasi belajar siswa pada materi pokok bangun datar, ternyata siswa yang mengikuti pembelajaran matematika dengan pendekatan kontekstual mempunyai nilai rata-rata yang lebih tinggi daripada siswa yang mengikuti pembelajaran dengan pendekatan konvensional. Hal ini menunjukkan bahwa secara teoritis hasil penetian ini dapat dijadikan sebagai salah satu acuan untuk meningkatkan atau mengoptimalkan prestasi belajar siswa khususnya, pada mata pelajaran matematika. 
Dengan menggunakan pendekatan kontekstual membuat siswa lebih aktif dalam kegiatan belajar, sebab siswa berfikir dan menggunakan kemampuan dirinya untuk belajar dalam pemahaman suatu konsep matematika. Selain itu, menggunakan pendekatan kontekstual membuat siswa lebih mudah memahami dan mengingat apa yang dipelajari, sebab dalam pembelajaran dengan menggunakan pendekatan kontekstual siswa dituntut untuk mengalami sendiri yang sedang dipelajari dan bukan hanya menghafal.

\section{Implikasi Praktis}

Hasil penelitian ini dapat digunakan sebagai masukan bagi guru dan calon guru dalam upaya peningkatan kualitas proses belajar mengajar dan prestasi belajar siswa. Dengan memperhatikan faktor-faktor yang mempengaruhi proses belajar mengajar, guru dapat memilih pendekatan pembelajaran yang tepat, efektif dan efisien serta memperhatikan aktivitas belajar siswa sehingga dapat meningkatkan prestasi belajar matematika siswa pada materi pokok bangun datar.

\section{Saran}

Berdasarkan kesimpulan dan implikasi di atas maka ada beberapa saran yang ditujukan pada guru, calon guru dan peneliti yaitu:

\section{Kepada guru mata pelajaran matematika}

a. Dalam pembelajaran matematika, guru harus dapat mengalokasikan waktu dengan tepat, serta membuat perangkat pembelajaran yang benar-benar efektif dan efesien, selain itu harus teliti dalam memilih benda sebagai media pembelajaran materi yang akan dipelajari sehingga dengan mudah dapat dipahami oleh siswa.

b. Pendekatan kontekstual merupakan salah satu alternatif pendekatan pembelajaran yang dapat digunakan oleh guru untuk meningkatkan prestasi belajar matematika oleh karena itu hendaknya guru mau mencoba pendekatan pembelajaran tersebut untuk mengajarkan pada materi pokok matematika.

\section{Kepada Siswa}

a. Sebaiknya para siswa mengikuti dengan aktif dalam kegiatan belajar mengajar, berusaha mengaplikasikan, selalu memperhatikan dan menghargai penjelasan, pendapat, pertanyaan atau jawaban yang disampaikan oleh siswa lain pada saat kegiatan belajar berlangsung agar 
kemampuan pemahamann konsep sebagai tujuan dalam belajar dapat tercapai.

b. Saat diskusi berlangsung, siswa yang memiliki kemampuan lebih dibandingkan dengan teman-teman yang lain hendaknya bersedia membagi pengetahuan kepada teman yang belum paham tentang suatu hal.

\section{Kepada Kepala Sekolah}

a. Hendaknya kepala sekolah menyarankan kepada guru matematika agar dalam memberikan pembelajaran dapat memperoleh hasil yang optimal harus memilih pendekatan pembelajaran yang mengaktifkan siswa, salah satu pendekatan pembelajaran yang dapat dipilih adalah pendekatan kontekstual.

b. Agar proses pembelajaran matematika dengan menggunakan pendekatan kontekstual dapat berjalan dengan baik dan menghasilkan prestasi belajar yang maksimal, sebaiknya kepala sekolah menyediakan fasilitas seperti kelas dengan tempat duduk dan meja yang sudah diatur untuk keperluan diskusi dan turnamen, sehingga setiap proses pembelajaran matematika akan belangsung dengan baik tidak banyak memakan waktu dan menimbulkan suara dan kegaduhan.

c. Sebaiknya, kepala sekolah menyediakan sarana dan prasarana yang dibutuhkan dalam pembelajaran matematika dengan pendekatan kontekstual agar pelaksanaannya dapat berjalan dengan baik memperoleh prestasi belajar yang maksimal.

\section{DAFTAR PUSTAKA}

Abu ahmadi, 1992. Diktatik Metodik.. PT. Toha Putra. Semarang

Abu Muhammad Ibnu Abdullah. 2009. Prestasi Belajar. http://spesialistorch.com/content/view/120/29/ dikutip pada tanggal 04 juli 2009.

Ahmad Muchlis. 2009. Belajar dari TIMSS 2007. (http:// www. antara.co. id/ arc/ 2008/7/24/ ri-raih- perak-perunggu-olimpiade-matematika-internasional) dikutip pada tanggal 18 juli 2009.

Budiyono. 2004. Statistika Untuk Penelitian. Surakarta : FKIP UNS Press. .2003. Metodelogi Penelitian Pendidikan. Surakarta : FKIP UNS Press. 
Departemen Pendidikan dan Kebudayaan. 2005. Kamus Besar Bahasa Indonesia. Jakarta: Balai Pustaka.

Depdiknas. 2003. Pendekatan Kontekstual (CTL). Depdikbud. Jakarta

Doantara yasa. 2008. Pendekatan Konstruktivisme Dan Kontekstual Pendidikan Sain. http://www.docstoc.com/docs/5103227/metodologi-ipa-sd_4. dikutip pada tanggal 15 Agustus 2009.

E Laine, Jhonson. Contextual Teaching and Learning (Menjadikan Kegiatan Belajar Mengajar Mengasyikkan dan Bermakna). Bandung. MLC

Gil Ignacio L, Nuria; J. Blanco N, Lorenzo; Guerrero B, Eloisa. 2006. "The Affective Domain in The Mathematics Learning". International Electronic Journal Of Mathematics Education. Volume 1, Number 1, 78-102. (www.iejme.com).

Hesson M dan Fatima S, Kaneez. 2007. A Student-Centered Learning Model. ”. International Electronic Journal of Mathematics Education Volume 4, Number 9. pp 628-636.University of Karachi, Pakistan. (www.iejme.com).

Idris, Noraini. 2009. "Enhancing Students' Understanding In Calculus Trough Writing". International Electronic Journal of Mathematics Education. Volume 4, Number 1. pp 36-55. Faculty Of Education, University of Malaysia Kuala Lumpur, Malaysia. (www.iejme.com).

Kennedy R. 2007. "In-Class Debates: Fertile Ground for Active Learning and the Cultivation of Critical Thinking and Oral Communication Skills". International Journal of Teaching and Learning in Higher Education. Volume 19, Number 2. pp 183-190. (http://www.isetl.org/ijtlhe/).

Kotsopoulos D dan Lavigne, Susan. 2008. Examining "Mathematics for Teaching" Through an Analysis of Teachers' Perceptions of Student "Learning Paths"1. International Electronic Journal of Mathematics Education. Volume 3, Number 1. pp 1306-3030. (www.iejme.com).

Nurhadi; Yasin B, dan Senduk, A. G. 2004. Pembelajaran Kontekstual dan Penerapannya dalam KBK. Malang : UM Press.

Pentatito G. 2008. Efektivitas Pendekatan Realistik dalam Menyelesaikan Soal Cerita dan Sikap Terhadap Matematika Ditinjau Dari Kemampuan Awal Siswa Kelas IV SD di Kecamatan Purworejo Kabupaten Purworejo. Tesis. Surakarta: program studi pendidikan matematika program pasca sarjana Universitas Sebelas Maret

Rosyidah fima. 2004. Pengembangan KBK Melalui Strategi Pembelajaran Kontekstual.(http://www.geocities.com/pakguruonline_pend_konteks_contoh3 . html) dikutip pada tanggal 23 februari 2009

Ruseffendi. 1988. Pendidikan Matematika 3. Jakarta. Depdikbud Pembinaan Tenaga Kependidikan Tinggi. 
Saifuddin Azwar. 2007. Pendekatan Penelitian. Yogyakarta:Pustaka Pelajar. Slameto. 2003. Evaluasi Pendidikan. Jakarta: PT. Bumi Aksara.

Soedjadi R. 2000. Kiat Pendidikan Matematika di Indonesia. Jakarta: Dirjen Pendidikan tinggi Depdiknas.

Suharsimi Arikunto. 1998. Manajemen Penelitian. P2LPK. Jakarta

Suharsimi Arikunto. 2009. Dasar-dasar Evaluasi Pendidikan. Jakarta Bumi Aksara.

Supardi. 2006. Pengaruh pendekatan kontekstual terhadap prestasi belajar matematika ditinjau dari intelegensi siswa SD negeri Kecamatan Andong. Tesis. Surakarta: program studi pendidikan matematika program pasca sarjana Universitas Sebelas Maret

Winkle. W. S. 1996. Psikologi Pengajaran. Jakarta: Grasindo

(http:// www.geocities.com /pakguruonline /pend_konteks_contoh3.html) dikutip pada tanggal 15 November 2008

(http://www.tutor.com.my/lada/tourism/edu-kontekstual.htm).dikutip pada tanggal 7 maret 2009

Yanti.2009. Diagnosis Kesulitan Belajar Matematika. www.freewebs.com/ arrosailtep/makalah/diagnosis kesulitan belajar matematika dikutip pada tanggal 15 Agustus 2009.

Zahorik.1995. Kaidah Pembelajaran Kontekstual. (http:// www.tutor.com.my/ lada/tourism/edu-kontekstual.htm dikutip pada tanggal 23 Maret 2009 